\title{
A dohányzás visszaszorítása a Facebook segítségével a 14-35 éves korosztály körében
}

\author{
Pócs Dávid dr. ${ }^{1}$ - Kovács Róbert ${ }^{1}$ - Óvári Tímea ${ }^{1}$ \\ Erdős Csaba ${ }^{2}$ - Kelemen Oguz dr. ${ }^{1}$ \\ 'Szegedi Tudományegyetem, Általános Orvostudományi Kar, Magatartástudományi Intézet, Szeged \\ ${ }^{2}$ Szegedi Tudományegyetem, Általános Orvostudományi Kar, Népegészségtani Intézet, Szeged
}

\begin{abstract}
Bevezetés: Minél kevesebb ideje dohányzik valaki, annál nagyobb az esélye a sikeres leszokásra. Ezért a 14-35 év közötti dohányzók leszokásának támogatása kulcsfontosságú a dohányzás hazai prevalenciájának csökkentésében. Ebben a korosztályban az egyik legnépszerúbb internetes felület a Facebook, mely alkalmas lehet korcsoport-specifikus leszokási támogatásra.

Célkitüzés: Kutatásunk arra törekszik, hogy feltárja egy leszokást segítő Facebook-oldal követésének hatásait a 14-35 éves korosztály dohányzási szokásaira és attitüdjére.

Módszer: A szerzők által több mint egy éve múködtett Facebook-oldal 3278 követője körében online felmérést végeztünk. A 14-35 éves korosztályból összesen 332 fö töltötte ki a kérdőívet $(\mathrm{n}=332)$. A demográfiai adatok mellett felmértük a válaszadók dohányzási szokásait, a Facebook-oldal használatának gyakoriságát és időtartamát, illetve a leszokással kapcsolatos ismeretek, dohányzási szokások és attitüdök változását.

Eredmények: A vizsgált populáció átlagéletkora 22,57 ¥ 5,08 év volt, melyből 65\% jelenleg dohányzó, 12\% leszokott dohányzó és 23\% nem dohányzó. Azok a jelenleg dohányzók, akik gyakrabban és hosszabb ideje használták a Facebook-oldalt, szignifikánsan többen számoltak be dohányzási szokásaik és leszokási attitűdjeik pozitív változásáról $(\mathrm{p}<0,05)$. Bár a leszokást tervezők között a szokások és attitűdök pozitív változása szignifikánsan nagyobb arányban fordult elő $(\mathrm{p}<0,01)$, azoknál is $12-25 \%$ közötti attitúdváltozást észleltünk, akik nem tervezték a leszokást. A nem dohányzók pozitív attitűdváltozása szignifikánsan magasabb volt a faluban élő, alacsony iskolázottságú lakosság körében $(\mathrm{p}<0,01)$.

Következtetés: A vizsgált Facebook-oldal pozitív irányban befolyásolta a 14-35 éves korosztály leszokási ismereteit, dohányzási szokásait és attitúdjeit. A Facebook-oldal tartalmai szabadon felhasználhatók a 14-35 éves páciensek leszokásának támogatásában, valamint a Facebook-oldal követése javasolható dohányzó és nem dohányzó fiataloknak egyaránt.
\end{abstract}

Orv Hetil. 2019; 160(6): 220-227.

Kulcsszavak: dohányzás, leszokás, fiatal felnőtt, közösségi média, Facebook

\section{Tobacco reduction on Facebook among 14-35-year-olds}

Introduction: The possibility of successful smoking cessation is increased by early initiation. Therefore, promoting smoking cessation at early age (especially among 14-35-year-olds) has a key role in reducing tobacco use prevalence. Facebook is one of the most popular websites among adolescents and young adults which can be used for age-specific smoking cessation support.

Aim: Our research seeks to reveal the effects of a Facebook page on smoking habits, smoking cessation knowledge and attitudes among 14-35-year-olds.

Method: An online survey was conducted among the 3278 followers of the author's Facebook page. The questionnaire was completed by 332 people among 14-35-year-olds. We analysed demographic data, smoking habits, the usage frequency and duration of the Facebook page as well as changes in smoking habits, smoking cessation knowledge and attitudes.

Results: The average age was $22.57 \pm 5.08$ years. The examined population consisted of $65 \%$ currently smokers, $12 \%$ former smokers and $23 \%$ non-smokers. Significantly more people reported a positive change in their smoking habits and smoking cessation attitudes among smokers who used the Facebook page more frequently and with longer duration $(\mathrm{p}<0.05)$. The habit and attitude changes were significantly higher among smokers who plan to quit smoking 
$(\mathrm{p}<0.01)$. Nevertheless, we also observed attitude changes between $12-25 \%$ among smokers who did not plan to quit. Among non-smokers, the positive attitude changes were significantly higher in the low-educated population who live in villages $(\mathrm{p}<0.01)$.

Conclusion: This Facebook page had a positive effect on smoking habits, smoking cessation knowledge and attitudes among 14-35-year-olds. The contents of the Facebook page could be used to prevent smoking and support smoking cessation among 14-35-year-olds.

Keywords: smoking, cessation, young adult, social media, Facebook

Pócs D, Kovács R, Óvári T, Erdős Cs, Kelemen O. [Tobacco reduction on Facebook among 14-35-year-olds]. Orv Hetil. 2019; 160(6): 220-227.

(Beérkezett: 2018. szeptember 21.; elfogadva: 2018. október 1.)

\section{Rövidítések}

OKJ = Országos Képzési Jegyzék; SZTE = Szegedi Tudományegyetem

A dohányzás a korai halálozás legfontosabb viselkedésbeli kockázati tényezője, hiszen összefüggésbe hozható a vezető halálokokkal [1]. A dohányzói életút különböző szakaszokra bontható, melyekre eltérő jellemzők vonatkoznak [2]. Az életkor szerint a dohányzás prevalenciája serdülőkorban fokozatosan emelkedik, a fiatal felnőtt populációban éri el a maximumát, majd az idősebb korosztályban fokozatosan csökken [1]. A leszokás tekintetében pedig közismert szakirodalmi adat, hogy minél kevesebb ideje dohányzik valaki, annál nagyobb a sikeres leszokási kísérlet esélye [1]. Tehát a 14-35 éves korosztályban fokozatosan emelkedik és tetőzik a dohányzás prevalenciája, a leszokási kísérletek ritkábbak, de sikeresebbek, mint az idősebb korosztályban. Ennek ellenére kevés az olyan jó minőségű klinikai vizsgálat, mely az erre a korosztályra specifikus leszokástámogató intervenciókat kutatná [3].

Összehasonlítva más korcsoportokkal, Curry és mtsai felmérése szerint a fiatal felnőtt korosztály sokkal kevésbé használ magatartásorvoslási vagy gyógyszeres segítséget a leszokáshoz [3], ellenben az internet használata széles körben elterjedt ebben a korcsoportban, ezért alkalmas lehet dohányzásleszokást támogató intervencióra [4]. A leszokástámogatás hazai irányelve a telefonos, egyéni és csoportos leszokástámogatási lehetőségek ismertetése mellett nem tér ki az internetes leszokástámogatási lehetőségekre [5]. Ez hazánkban még kevéssé kutatott terület, a hazai szakirodalom áttekintése során nem találtunk az internetes leszokástámogatással foglalkozó vizsgálatokat. Ezzel a közleménnyel többek között ez a hiánypótlás is a célunk.

Az applikációk és az internetes leszokást segítő lehetőségek népszerűek, könnyen elérhetők és hozzáférhetők, illetve szabadon használhatók a serdülők körében [6], illetve a fiatal felnőtt korosztályban is [4]. Taylor és mtsai összefoglaló tanulmánya szerint az internetes leszokástá- mogatás sokkal sikeresebb, ha interaktív [7]. A hagyományos internetes felületekkel szemben a közösségi média jellemzően nagyobb aktivitást követel a felhasználóktól [8], ezért a leszokás támogatása mellett a dohányzásprevencióban is kiemelt szerepe lehet. A közösségi média felületén megtalálhatók dohányipari cégek is, amelyek különböző marketingtartalmakat osztanak meg. Magyarországi serdülők körében végzett kutatás igazolta, hogy az alacsony médiatudatosság összefüggésbe hozható a dohányzással [9].

A közösségi média legnépszerűbb felülete a Facebook, mely az interaktivitás megteremtése mellett segítheti a szociális háló és társas támogatás kiépítését is. Nabi és mtsai szerint ez előnyös lehet a leszokástámogatásban, de más egészségügyi probléma megoldásában is [10]. A Facebook a népszerüsége és napi alkalmazása miatt kiaknázatlan lehetőséget nyújt a dohányzásleszokás támogatására a fiatalok körében [4].

Ezért kutatásunk célkitűzése, hogy feltárja egy leszokást segítő Facebook-oldal követésének hatásait a 14-35 éves korosztály dohányzási szokásaira és attitűdjére. A vizsgált „CigiSzünet” elnevezésű oldal (www.facebook. com/cigiszunet) 2017.03.07-én indult, és a közlemény szerzői múködtetik. A szerkesztésbe egy egyetemi kurzus keretei között bekapcsolódtak a Szegedi Tudományegyetem hallgatói is (fóleg orvostanhallgatók). Tudomásunk szerint hazánkban ez az első, nonprofit jellegú, leszokást támogató Facebook-oldal, mely több mint 3000 követővel rendelkezik. A Facebook-oldal különlegessége, hogy a leszokástámogatásban sikeresen alkalmazott „motivációs interjú” elnevezésű tanácsadási szemléletre támaszkodik [11]. Ennek a szemléletnek megfelelően empatikus, együttmúködésre törekvő és leszokási motivációt feltáró tartalmakat használ, illetve kerüli a dohányzókat elítélő hangnemet és a félelmet keltő tartalmakat [11]. Továbbá nemcsak a jelenleg dohányzókat igyekszik megszólítani, hanem a leszokott dohányosokat és a nem dohányzókat is. Ezért a dohányzás társadalmi megítélésével kapcsolatos témákkal is foglalkozik (például passzív dohányzás, leszokni vágyók segítése, „denormalizálás”). A vizsgált oldal demográfiai jellemzőit 2018. 06. 27-én 
letöltöttük a Facebook felületéról, és az 1. táblázatban összegeztük. A jelzett időpontig összesen 64458 forintot költöttünk Facebook-hirdetésekre, melyeket 63794 Facebook-felhasználó legalább egyszer látott. A hirdetések eredménye összesen 2565 oldalkedvelés volt. Más költsége az intervenciónak nem volt.

1. táblázat | A vizsgált Facebook-oldal demográfiai jellemzői 2018. 06. 27. én a felhasználók Facebook-adatai alapján

\begin{tabular}{llll}
\hline & $\begin{array}{l}\text { Az oldal } \\
\text { követói } \\
2018.06 . \\
27-e ́ n\end{array}$ & $\begin{array}{l}\text { Elért } \\
\text { személyek } \\
\text { az elmúlt } \\
28 \text { napban }\end{array}$ & $\begin{array}{l}\text { Aktív } \\
\text { felhasználók } \\
\text { az elmúlt } \\
7 \text { napban }\end{array}$ \\
\hline Összesen & 3278 fó & 32567 fó & 1076 fó \\
Átlagéletkor & 26 év & 28 év & 27 év \\
Nő-férfi arány & $49 \%-51 \%$ & $45 \%-55 \%$ & $49 \%-51 \%$ \\
Külföldi tartózkodás & 101 fó & 2105 fó & 52 fó \\
$\begin{array}{l}\text { Magyarországi } \\
\text { tartózkodás }\end{array}$ & 3177 fó & 30462 fó & 1024 fó \\
\hline
\end{tabular}

Az oldal követői: akik követik az oldal új bejegyzéseit. Elért személyek: akik legalább egyszer látták az oldal bejegyzéseit. Aktív felhasználók: akik az oldal bejegyzéseinél aktívak voltak („like”, reakció, megosztás, komment)

\section{Módszer}

Online kérdőív segítségével gyưjtöttünk adatokat az oldal követőitől kéthetes időintervallumban (2018. 06. 24. és 2018. 07. 08. között). Az oldal szerkesztősége nem töltötte ki a kérdőívet. A közösségi médiával kapcsolatos kutatások gyakori módszere a Facebook-hirdetés és a nyereményjáték használata [8], melyeket mi is alkalmaztunk. Továbbá az oldal bejegyzéseiben hívtuk fel a követők figyelmét a kitöltés lehetőségére. A magyar nyelvű kérdőív kitöltése önkéntes volt, az anonimitást biztosítottuk. Összesen 358 válasz érkezett. A legfiatalabb kitöltő 14 éves volt. Kizártuk azokat, akik a 35. életévüket betöltötték ( 25 fö). Így a 14-35 éves korosztályból összesen 332 fó válaszát elemeztük $(\mathrm{n}=332)$. A statisztikai számításokhoz SPSS-programot (SPSS Inc., Chicago, IL, Amerikai Egyesüt Államok) használtunk, és Pearson-féle khí-négyzet-próbát, illetve (Levene-próbát követően) kétmintás t-próbát alkalmaztunk. Kutatásetikai engedélyünket a Szegedi Tudományegyetem SzentGyörgyi Albert Klinikai Központjának Humán Orvosbiológiai Regionális és Intézményi Kutatásetikai Bizottsága adta (96/2016-SZTE).

A kérdőív első részében a kutatás szempontjából releváns demográfiai jellemzőket mértük fel: a válaszadó nemét, életkorát, lakhelyét, foglalkozását, legmagasabb iskolai végzettségét és nemzetiségét. Ezután dohányzási státusz szerint csoportosítottuk a válaszadókat. Nem dohányzónak tekintettük, akik a kérdőív kitöltésekor és korábban sem dohányoztak. Leszokott dohányzónak tekintettük azokat, akik a kérdőív kitöltésekor nem dohányoztak, de életük során több mint 100 szál cigarettát szívtak el [11, 12]. Végül jelenleg dohányzónak tekintettük azokat, akik a kérdőív kitöltésekor dohányzónak vallották magukat, és fogyasztottak valamilyen dohányterméket. A dohányzókat további 3 szempont szerint csoportosítottuk. Dohányzási gyakoriság szerint elkülönítettük a rendszeresen (naponta) dohányzókat és az alkalmi (napi rendszerességnél ritkábban) dohányzókat. Nikotinfüggőnek tekintettük azokat, akik a felkelést követően 30 percen belül rágyújtanak $[13,14]$. A dohányzók körében továbbá felmértük az alternatív dohánytermékek használatát, az elmúlt 24 órát meghaladó leszokási kísérleteit, illetve hogy hány éve dohányzik. Végül leszokási stádium szerint is csoportosítottuk a jelenleg dohányzókat („Tervezi-e, hogy leszokik a dohányzásról?”), illetve a leszokás folyamatában lévő absztinenseket („Mikor szokott le a dohányzásról, 12 hónapon belül?") $[6,15]$. A leszokási stádiumok a szakirodalom szerint: „töprengés” (nem tervezi a leszokást), „elhatározás” (6 hónapon belül tervezi a leszokást), „előkészület” (30 napon belül tervezi a leszokást), „leszokás” (kevesebb mint 6 hónapos absztinencia), „fenntartás" (6-12 hónapos absztinencia) [6, 15].

Ezt követően a vizsgált Facebook-oldal használatát mértük fel. A Facebook-oldal látogatási gyakorisága szerint („Milyen gyakran nézed meg az oldal posztjait?”) 3 csoportot különítettünk el (napi, heti és ritkább látogatás). A Facebook-oldal követésének időtartama szerint ( Mióta követed az oldalunkat?”) szintén 3 csoportot különítettünk el (1 hónapnál kevesebb, 1-6 hónap közötti, 6 hónapnál hosszabb követés). A kérdőív további része a válaszadók saját bevallása alapján az új leszokási ismereteket, a dohányzási szokások és a dohányzással kapcsolatos attitűdök változását mérte fel a vizsgált Facebook-oldallal összefüggésben. A jelenleg dohányzó csoportban megvizsgáltuk a Facebook-oldalon szerzett új ismereteket a leszokással kapcsolatban („Milyen leszokássegítő lehetőséget ismertél meg az oldalon keresztül?”), a dohányzási szokások változását ( „Amióta a CigiSzünet oldalt követed, megváltoztak-e a dohányzási szokásaid?”), illetve a leszokással kapcsolatos attitűdváltozást („Amióta a CigiSzünet oldalt követed, fontosabb lett-e számodra a leszokás, illetve nőtt-e az önbizalmad a leszokással kapcsolatban?”). A leszokott dohányosok csoportjában megvizsgáltuk a Facebook-oldal leszokási támogató hatását („A CigiSzünet oldal követése óta szoktál le, és az oldal posztjai segítettek ebben?”), illetve a relapsus prevencióra gyakorolt hatását („A CigiSzünet oldal követése segít-e abban, hogy 'füstmentes' maradj?”). A nem dohányzó csoportban a leszokás támogatásával kapcsolatos attitüdváltozást („Amióta a CigiSzünet oldalt követed, fontosabb lett-e számodra, hogy segítsd a dohányzókat a leszokásban?") és a passzív dohányzás elleni védekezéssel kapcsolatos attitűdváltozást mértük fel („Amióta a CigiSzünet oldalt követed, fontosabb lett-e számodra, hogy megvédd magad és másokat a passzív dohányzástól?”). 


\section{Eredmények}

\section{Demográfia és dohányzási szokások}

A vizsgált $14-35$ éves populáció $(\mathrm{n}=332$ ) átlagéletkora $22,57 \pm 5,08$ év. A nemi eloszlás tekintetében $61 \%$-a nő és 39\%-a férfi. Lakhely szerint a válaszadók $18 \%$-a él a fóvárosban, 19\%-a megyeszékhelyen, 39\%-a városban, $23 \%$-a faluban és $1 \%$-a községben vagy tanyán. A vizsgált populáció $45 \%$-a tanuló, $45 \%$-a dolgozik, végül $10 \%$-a nem dolgozik, gyermekgondozási díjban vagy segélyben részesül. A legmagasabb iskolai végzettség tekintetében a válaszadók 15\%-a egyetemet vagy fóiskolát végzett, 58\%-a középiskolát vagy gimnáziumot, 23\%-a alapfokú iskolát (nyolc általánost), végül 4\%-a rendelkezik más jellegú végzettséggel (OKJ, szakmunka), vagy nincs iskolai végzettsége. A válaszadók $94 \%$-a vallotta magát magyarnak, $4 \%$-a roma vagy cigány nemzetiségúnek és $2 \%$-a más nemzetiségúnek.

A dohányzási státusz szerint a válaszadók 65\%-a (217 fó) jelenleg dohányzó, 12\%-a (45 fó) leszokott dohányzó és 23\%-a (70fó) nem dohányzó. A jelenleg dohányzók átlagosan $7 \pm 5$ éve dohányoznak, 94\%-uk rendszeresen (naponta), míg 6\%-uk alkalomszerúen. A reggeli első cigaretta elszívásának időtartama szerint a jelenleg dohányzók 55\%-a nikotinfüggő. A leggyakrabban használt dohánytermék a cigaretta volt (98\%), ezt követte az e-cigaretta (32\%), a vízipipa (20\%), a szivar és szivarka (6-6\%), illetve a snüsz, a pipa és a tubák használata (2-2$2 \%)$. Egyfajta terméket használt a dohányzó válaszadók $59 \%$-a (57\% cigarettát, 2\% e-cigarettát), míg $41 \%$-uk többféle terméket használt (11\% nem használt elektronikus terméket, $30 \%$ a cigarettát és az e-cigarettát együtt használta, azaz 'dual user' volt). A jelenleg dohányzó vá- laszadók 53\%-ának volt 24 órát meghaladó leszokási kísérlete az elmúlt egy éven belül, 26\%-uknak egy évnél régebben, és $21 \%$-uknak nem volt még 24 órát meghaladó leszokási kísérlete. Összesen 251 válaszadót kategorizáltunk a leszokási stádiumok szerint. A jelenleg dohányzók közül 75 fó nem tervezte a leszokást, illetve 116 fó hosszú távon ( 6 hónapon belül) és 26 fö rövid távon (30 napon belül) tervezte a leszokást. A leszokottak közül 25 fő kevesebb mint 6 hónapja, míg 9 fó 6-12 hónapja volt absztinens.

\section{Az ismeretek, szokások és attitüdök változása}

A jelenleg dohányzók saját bevallása szerint a Facebookoldalnak köszönhetően 59\%-uk szerzett új ismereteket a leszokással kapcsolatban (például leszokást segítő gyógyszerekről, applikációkról, honlapokról, telefonos, egyéni és csoportos szaksegítségről), és 53\%-uk számolt be dohányzási szokásainak valamilyen pozitív változásáról (például 29\% csökkentette a dohánytermék adagját, 27\% dohányzáskor odafigyel másokra, $12 \%$ átmenetileg felhagyott a dohányzással). Ezenkívül a jelenleg dohányzó válaszadók 49\%-a számára fontosabb lett a leszokás, illetve $52 \%$-uk szerint nőtt az önbizalmuk a leszokással kapcsolatban. A leszokott dohányosok 36\%-a a Facebookoldal követése óta hagyott fel a dohánytermékek fogyasztásával (9\% számára nem segítettek, azonban $27 \%$ számára saját bevallásuk szerint segítséget jelentettek az oldal posztjai). Emellett a leszokott dohányosok 73\%-a nyilatkozott arról, hogy a Facebook-oldal követése segített a relapsus megelózésében. Végül a nem dohányzó válaszadók $61 \%$-a számolt be valamilyen pozitív változásról a dohányzással kapcsolatos attitû́djének tekintetében

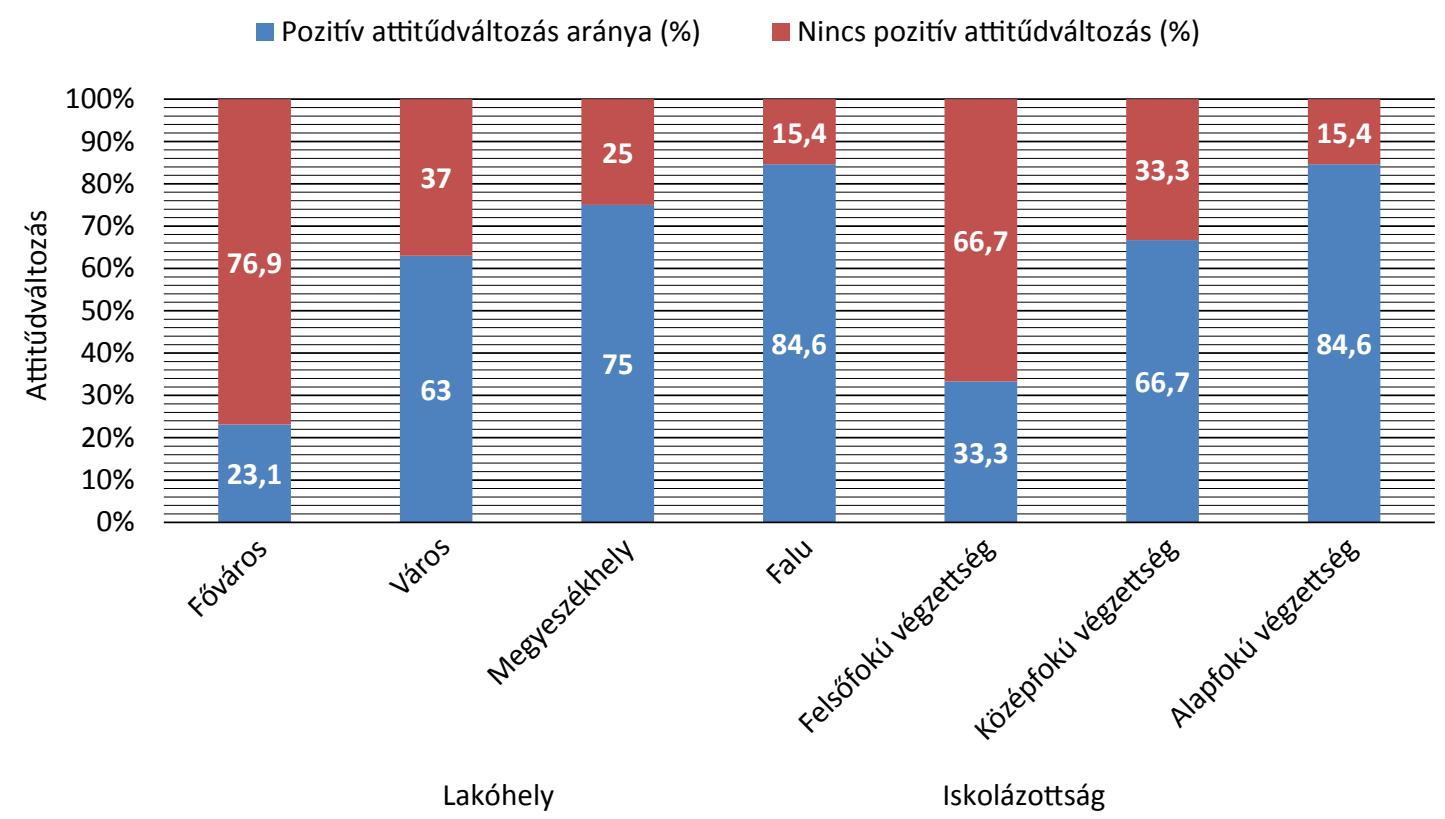

1. ábra $\quad$ A nem dohányzók pozitív attitűdváltozása a lakóhely és az iskolázottság függvényében. A nem dohányzók pozitív attitűdváltozással kapcsolatos válaszainak ábrázolása a lakóhely (első 4 oszlop) és az iskolázottság (utolsó 3 oszlop) szerint 
(például 40\% számára fontosabb lett, hogy segítse a dohányzókat a leszokásban, 46\% számára fontosabb lett, hogy megvédje magát a passzív dohányzástól, 29\% számára fontosabb lett, hogy megvédjen másokat a passzív dohányzástól).

Összevetettük a vizsgált csoport demográfiai jellemzőit és az ismeretek, szokások és attitűdök változását. A nem dohányzó, faluban élő válaszadók szignifikánsan többen számoltak be a dohányzással kapcsolatos attitüdjüknek valamilyen pozitív változásáról, mint a nem dohányzó, nagyobb lakosságú településen élő válaszadók $\left(c^{2}(4)=13,883, p<0,01\right)$. Hasonló szignifikáns összefüggést találtunk az iskolázottság tekintetében $\left(c^{2}(2)=\right.$
9,398, p<0,01). Ezeket az eredményeket az 1. ábrán szemléltetjük. Továbbá a nem dohányzók pozitív attitüdváltozása a fiatalabb válaszadókra volt jellemzőbb (átlagéletkor: $21,02 \pm 4,11$ ), szemben azokkal, akiknél nem volt attitűdváltozás (átlagéletkor: $23,78 \pm 5,24$ ). Ez a különbség kétmintás t-próbával szignifikánsnak bizonyult $(\mathrm{t}(68)=-2,45, \mathrm{p}<0,05)$. Szignifikáns nemi különbséget, illetve foglalkozás vagy nemzetiség szerinti statisztikai eltérést nem találtunk.

Ezt követően a vizsgált Facebook-oldal használatával hasonlítottuk össze az ismeretek, szokások és attitűdök változását. A jelenleg dohányzó csoportban találtunk szignifikáns összefüggéseket, melyeket a 2. ábrán muta-
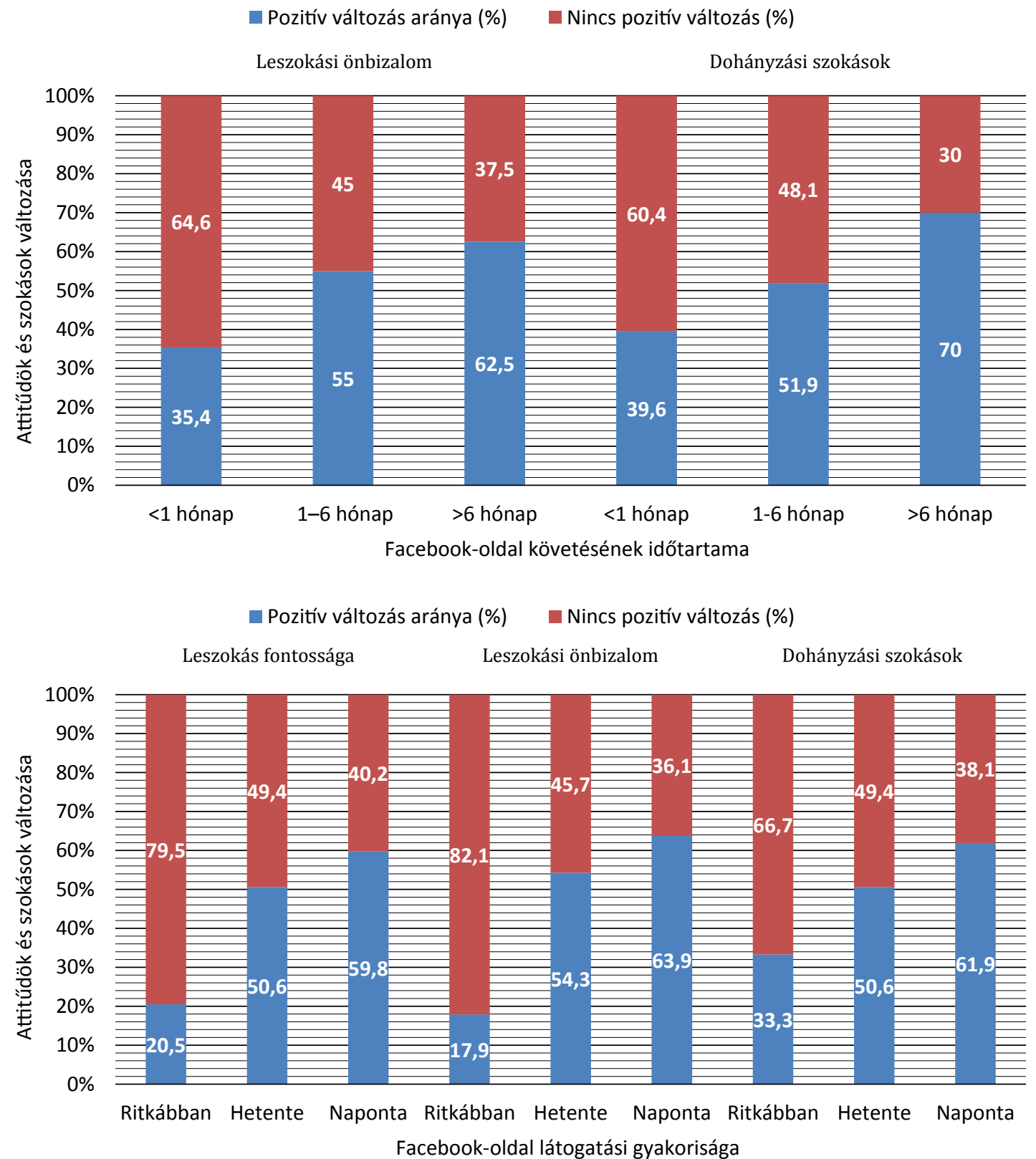

2. ábra

A jelenleg dohányzók attitűdjének és dohányzási szokásainak változása a Facebook-oldal használatával összehasonlítva. Felső diagram: a Facebookoldal követési időtartamának ábrázolása a leszokási önbizalom (bal oldali 3 oszlop) és a dohányzási szokások (jobb oldali 3 oszlop) szerint. Alsó diagram: a Facebook-oldal látogatási gyakoriságának ábrázolása a leszokás fontossága (bal oldali 3 oszlop), a leszokási önbizalom (középső 3 oszlop) és a dohányzási szokások (jobb oldali 3 oszlop) szerint 
tunk be. A jelenleg dohányzó válaszadóink minél gyakrabban látogatták a Facebook-oldalt, annál fontosabbá vált számukra a leszokás $\left(c^{2}(2)=17,260, p<0,01\right)$, annál inkább nőtt a leszokással kapcsolatos önbizalmuk $\left(\mathrm{c}^{2}(2)\right.$ $=23,814, \mathrm{p}<0,01)$, és annál többen számoltak be dohányzási szokásaik pozitív változásáról $\left(c^{2}(2)=9,265\right.$, $\mathrm{p}<0,05)$. Hasonló összefüggést találtunk a Facebook-oldal követésének időtartamának vonatkozásában. A jelenleg dohányzó válaszadóink minél régebb óta követték a Facebook-oldalt, annál inkább nőtt a leszokási önbizalmuk $\left(c^{2}(2)=7,533, p<0,05\right)$ és annál inkább változtattak dohányzási szokásaikon $\left(\mathrm{c}^{2}(2)=8,140, \mathrm{p}<0,05\right)$. A leszokott dohányosok és a nem dohányzók csoportjában nem találtunk szignifikáns eltéréseket az attitűdváltozás és a Facebook-oldal használata között.

Végezetül megvizsgáltuk a leszokási stádiumok és az ismeretek, szokások és attitűdök változása közötti összefüggéseket. A leszokási stádiumok első három („töprengés”, „elhatározás”, „előkészület”) stádiumának elemszáma felelt meg a Pearson-féle khí-négyzet-próba feltételeinek, így ezt a három stádiumot vizsgáltuk meg, és a szignifikáns eredményeket a 3. ábrán szemléltetjük. A jelenleg dohányzók közül azoknak, akik hosszú vagy rövid távon tervezték a leszokást, szignifikánsan nagyobb arányban vált fontosabbá a leszokás, amióta követik a Facebook-oldalt $\left(c^{2}(2)=63,827, p<0,01\right)$, jelentősebben nött a leszokással kapcsolatos önbizalmuk $\left(\mathrm{c}^{2}(2)=\right.$ $36,681, p<0,01)$, és többen számoltak be dohányzási szokásaik pozitív változásáról $\left(\mathrm{c}^{2}(2)=35,091, \mathrm{p}<0,01\right)$, szemben azokkal, akik nem tervezték a leszokást. Emellett az a szignifikanciaközeli tendencia is megfigyelhető volt $\left(c^{2}(8)=14,943, p=0,06\right)$, hogy a Facebook-oldal napi látogatási gyakorisága folyamatosan növekedett a leszokási stádiumok előrehaladtával. Azaz minél rövidebb távon tervezte a dohányzó fiatal a leszokást, annál intenzívebben használta a Facebook-oldalt.

\section{Megbeszélés}

Felmérésünk szerint a vizsgált Facebook-oldal sikeresen megszólította elsődleges célközönségét, a jelenleg dohányzó fiatalokat, akik a 14-35 éves válaszadók közel kétharmadát (65\%-át) alkották. A leszokási ismeretek gyarapodása, illetve a dohányzási szokások és leszokási attitüdök pozitív változása összességében $50 \%$ körüli volt a jelenleg dohányzók körében. Ha ezt az eredményt az oldal követőire vetítjük (95\%-os konfidenciaszint és 5,1es konfidenciaintervallum mellett), akkor megbecsülhető, hogy a Facebook-oldal 1065 ( \pm 108$)$ dohányzó körében érte el a leszokási ismeretek gyarapodását, illetve a dohányzási szokások és leszokási attitűdök pozitív változását. Ha ezt összevetjük a bevezetésben ismertetett költségekkel (64 458Ft), akkor kiszámolható, hogy ez az eredmény alacsony, $61( \pm 6)$ forintos költséggel járt dohányzónként. Az internetes leszokástámogató intervencióknak ezt a költséghatékony tulajdonságát más külföldi tanulmányok is megerősítik $[7,8]$.

Vizsgálatunk demográfiai adatai rámutatnak arra, hogy a vizsgált intervenció képes megszólítani a falvakban élő lakosságot is. A közösségi média földrajzi távolságokon átívelő szerepére már Kim és mtsai is felhívták a figyelmet [16]. Továbbá eredményeink szerint a falusi, alacsony iskolázottságú nem dohányzók körében a dohányzással kapcsolatos pozitív attitűdváltozás szignifikánsan magasabb volt, azaz fontosabb lett számukra, hogy segítsék a dohányzókat a leszokásban, és védekez-

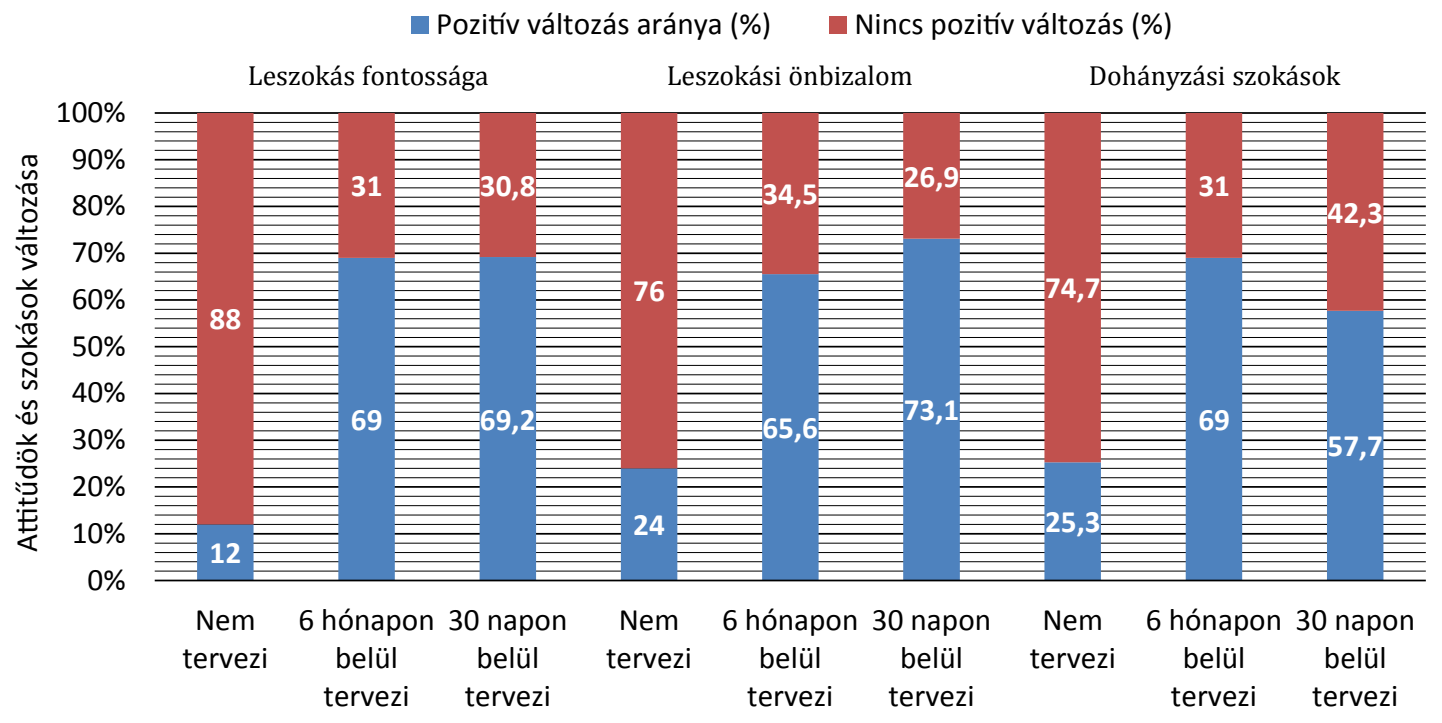

A leszokás tervezése (leszokási stádiumok) 
zenek a passzív dohányzás ellen. A szakirodalomban nem találtunk ezt a jelenséget magyarázó eredményt, ezért ezen a területen további vizsgálatok javasoltak. Ugyanakkor meglátásunk szerint ez az eredmény talán azzal magyarázható, hogy a nagyobb településeken élőknél és a magasabb iskolázottságúaknál ezek a pozitív attitűdök már a Facebook-oldaltól függetlenül is nagyobb arányban jelen lehettek.

Azon jelenleg dohányzó, 14-35 éves válaszadók közül, akik gyakrabban és hosszabb ideje használták a Facebook-oldalt, szignifikánsan többen számoltak be dohányzási szokásaik és leszokási attitűdjeik pozitív változásáról. A Facebook-felhasználók aktivitása, elköteleződése más külföldi tanulmány szerint is segíti a dohányzási szokások pozitív változását és a leszokást [16]. A szokások és attitűdök pozitív változása szignifikánsan nagyobb arányban fordult elő azokban a leszokási stádiumokban, amelyekben tervezték a leszokást. Ezt az magyarázhatja, hogy a leszokási motiváció erősödésével szignifikánsan nő a dohányzó fiatalok érdeklődése a Facebook leszokással kapcsolatos tartalmai iránt, amit Ramo és mtsai kutatása is megerősít [17]. Ezért a jövőben további kutatási irányként és intervenciós lehetőségként tekintünk a leszokási stádiumokhoz igazodó, leszokástámogató Facebook-csoportok indítására, más külföldi példákhoz hasonlóan [18].

\section{Következtetés}

Felmérésünk rámutatott, hogy egy leszokástámogató Facebook-oldal, mely kerüli a dohányzókat elítélő hangnemet és a félelmet keltő tartalmakat [11], jelentősen befolyásolhatja a 14-35 éves korosztály leszokási ismereteit, dohányzási szokásait és attitűdjeit. Ez a korosztály az interneten hatékonyabban szólítható meg, mint személyesen az egészségügyi rendszer által [7]. A telefonos, egyéni és csoportos leszokástámogatási lehetőségeket elsősorban a leszokás irányában már motivált dohányzók keresik fel és használják [5]. Ezért meglátásunk szerint fontos az attitűdformálás azok között, akik jelenleg nem vagy csak hosszú távon tervezik a leszokást. Eredményeink alátámasztják, hogy a Facebookon keresztül ezt a nehezen megszólítható csoportot is képesek lehetünk elérni és attitüdjüket formálni. Természetesen az internetes oldalunk számos helyen népszerüsít más, a hazai irányelven alapuló leszokástámogatási lehetőségeket, elérhetőségeket is $[5,19]$.

A Facebook-oldal tartalmai szabadon felhasználhatók a hazai fiatal korosztály leszokásának támogatásában. Különösen ajánljuk az érdeklődő kollégák figyelmébe a "Leszokásra motiváló posztok”, a „Leszokási tippek” vagy a leszokást segíto „Appok és honlapok” albumokat. A leszokástámogatás mellett a dohányzásprevenció területén is felhasználhatók az oldal tartalmai, például a "Sztárok, akik leszoktak”, a „Tévhitek a dohányzásról” vagy „Az e-cigi” albumokban található posztok. Reményeink szerint a közleményben ismertetett és vizsgált
Facebook-oldalt a jövőben tovább fejleszthetjük, és sikerülhet még ismertebbé tenni a hazai 14-35 éves korosztályban.

Anyagi támogatás: A közlemény megírása anyagi támogatásban nem részesült.

Szerzôi munkamegosztás: P. D., K. O.: A téma felvetése, a kutatás megtervezése. K. R., Ó. T.: Az adatok feldolgozása, a toborzás szervezése. E. Cs.: Az adatok elemzése, statisztika. P. D., K. R., Ó. T., K. O.: A Facebookoldal szerkesztése, üzemeltetése. P. D., K. R., Ó. T., E. Cs., K. O.: A kézirat megfogalmazása, ellenőrzése. A cikk végleges változatát valamennyi szerző elolvasta és jóváhagyta.

Érdekeltségek: A szerzőknek nincsenek érdekeltségeik.

\section{Irodalom}

[1] The health consequences of smoking - 50 years of progress: A report of the Surgeon General. U.S. Department of Health and Human Services, Centers for Disease Control and Prevention, National Center for Chronic Disease Prevention and Health Promotion, Office on Smoking and Health, Atlanta, GA, 2014. Available from: http://www.surgeongeneral.gov/ library/reports/50-years-of-progress/full-report.pdf [accessed: July 7, 2018].

[2] Pénzes M, Czeglédi E, Balázs P, et al. Smoking trajectories among Hungarian adolescents. [Dohányzói életutak magyar serdülők körében.] Orv Hetil. 2017; 158: 67-76. [Hungarian]

[3] Curry SJ, Sporer AK, Pugach O, et al. Use of tobacco cessation treatments among young adult smokers: 2005 National Health Interview Survey. Am J Public Health 2007; 97: 1464-1469.

[4] Ramo DE, Thrul J, Chavez K, et al. Feasibility and quit rates of the Tobacco Status Project: a Facebook smoking cessation intervention for young adults. J Med Internet Res. 2015; 17: e291.

[5] College of Health Professional, State Secretariat for Health, Hungarian Ministry of Human Resources. National guideline of smoking cessation support, 2014. [Emberi Erőforrások Minisztériuma, Egészségügyi Államtitkárság, Egészségügyi Szakmai Kollégium. Egészségügyi szakmai irányelv - A dohányzásról való leszokás támogatásáról, 2014.] Available from: https://tudogyogyasz.hu/Media/Download/12698 [accessed: July 7, 2018]. [Hungarian]

[6] Pócs D, Barabás K, Kelemen O. Interventions in medical practice to reduce tobacco use among adolescent. [Intervenciók az orvosi gyakorlatban a serdülőkori dohányzás visszaszorítására.] Orv Hetil. 2018; 159: 593-602. [Hungarian]

[7] Taylor GM, Dalili MN, Semwal M, et al. Internet-based interventions for smoking cessation. Cochrane Database Syst Rev. 2017; 9: CD007078.

[8] Naslund JA, Kim SJ, Aschbrenner KA, et al. Systematic review of social media interventions for smoking cessation. Addict Behav. 2017; 73: 81-93.

[9] Pikó B, Balázs MÁ, Page RM. The significance of media literacy in adolescent smoking and drinking. [A médiatudatosság jelentősége a serdülők dohányzásában és alkoholfogyasztásában.] LAM 2010; 20: 143-147. [Hungarian]

[10] Nabi RL, Prestin A, So J. Facebook friends with (health) benefits? Exploring social network site use and perceptions of social support, stress, and well-being. Cyberpsychol Behav Soc Netw. 2013; 16: 721-727. 
[11] Pócs D, Hamvai Cs, Kelemen O. Health behavior change: motivational interviewing. [Magatartás-változtatás az egészségügyben: a motivációs interjú.] Orv Hetil. 2017; 158: 1331-1337. [Hungarian]

[12] Centers for Disease Control and Prevention (CDC). Vital signs: current cigarette smoking among adults aged $\geq 18$ years - United States, 2009. Morb Mortal Wkly Rep. 2010; 59: 1135-1140.

[13] Sockrider M, Rosen JB, Redding G, et al. Prevention of smoking initiation in children and adolescents. Available from: http:// www.uptodate.com/contents/prevention-of-smoking-initiation-in-children-and-adolescents [accessed: July 7, 2018].

[14] Baker TB, Piper ME, McCarthy DE, et al. Time to first cigarette in the morning as an index of ability to quit smoking: implications for nicotine dependence. Nicotine Tob Res. 2007; 9(Suppl 4): S555-S570.

[15] DiClemente CC, Prochaska JO, Fairhurst SK, et al. The process of smoking cessation: an analysis of precontemplation, contemplation, and preparation stages of change. J Consult Clin Psychol. 1991; 59: 295-304.
[16] Kim SJ, Marsch LA, Brunette MF, et al. Harnessing Facebook for smoking reduction and cessation interventions: Facebook user engagement and social support predict smoking reduction. J Med Internet Res. 2017; 19: el68.

[17] Ramo DE, Liu H, Prochaska JJ. A mixed-methods study of young adults' receptivity to using Facebook for smoking cessation: if you build it, will they come? Am J Health Promot. 2015; 29: el26-el35.

[18] Ramo DE, Thrul J, Delucchi KL, et al. The Tobacco Status Project (TSP): study protocol for a randomized controlled trial of a Facebook smoking cessation intervention for young adults. BMC Public Health 2015; 15: 897.

[19] Kovács G. Smoking cessation support. [Dohányzás leszokás támogatás.] Háziorv Továbbk Szle. 2010; 15: 17-21. [Hungarian]

(Pócs Dávid dr.,

Szeged, Hajnóczy u. 13. 1/3, 6722 e-mail: drpocsdavid@gmail.com)

\title{
Országos Korányi Pulmonológiai Intézet - Budapest
}

\author{
a „Közalkalmazottak jogállásáról szóló” 1992. évi XXXIII. törvény 20/A. \ alapján \\ pályázatot hirdet \\ Országos Korányi Pulmonológiai Intézet - Budapest \\ kardiológus szakorvos \\ munkakör betöltésére.
}

\section{A közalkalmazotti jogviszony időtartama:}

Határozatlan idejü közalkalmazotti jogviszony.

Foglalkoztatás jellege:

Teljes munkaidő.

A munkavégzés helye:

Budapest, 1121 Budapest, Pihenő út 1.

A munkakörbe tartozó, illetve a vezetői megbízással járó lényeges feladatok:

Szakorvosi feladatok ellátása a Kardiológiai Rehabilitációs Osztályon és a területi ellátási kötelezettséggel is rendelkezö, jól felszerelt Kardiológiai Ambulancián. Osztályos munka. Ambuláns és konziliárusi betegellátás.

\section{Illetmény és juttatások:}

Az illetmény megállapítására és a juttatásokra a „Közalkalmazottak jogállásáról szóló” 1992. évi XXXIII. törvény, valamint a(z) OKPI Munkaügyi Szabályzata rendelkezései az irányadók.

\section{Pályázati feltételek:}

Egyetem, kardiológus szakvizsga

Echokardiográfiás gyakorlat szükséges

Büntetlen előélet

MOK tagság

Érvényes működési engedély

A pályázat elbírálásánál elönyt jelent:

Egyetem, további szakvizsga,

angol nyelvű nyelvvizsga, alapszintű nyelvtudás

A pályázat részeként benyújtandó iratok, igazolások:

Részletes szakmai önéletrajz,

végzettséget, szakképzetséget igazoló okiratok másolata, pozitív elbírálás esetén 3 hónapnál nem régebbi hatósági erkölcsi bizonyítvány

MOK tagság,

az Intézet honlapján megtalálható dátummal, aláírással ellátott adatkezelési hozzájáruló nyilatkozat.

A munkakör betölthetőségének időpontja:

A munkakör a pályázatok elbírálását követően azonnal betölthetö.

A pályázat benyújtásának határideje: 2019. február 25 .

A pályázati kiírással kapcsolatosan további információt

Dr. Czibók Csilla osztályvezető főorvos nyújt, a 06 30/5498250-os telefonszámon.

\section{A pályázatok benyújtásának módja:}

Postai úton, a pályázatnak a Országos Korányi Pulmonológiai Intézet - Budapest címére történő megküldésével (1121 Budapest, Pihenő út 1. ). Kérjük a borítékon feltüntetni a pályázati adatbázisban szereplő azonosító számot: 201901/kardszakorv , valamint a munkakör megnevezését: kardiológus szakorvos. Elektronikus úton Dr. Czibók Csilla osztályvezető főorvos részére a czibok@koranyi.hu e-mail címen keresztül.

A pályázat elbírálásának határideje: 2019. február 28. A pályázati kiírás további közzétételének helye, ideje: www.koranyi.hu www.kozigallas.hu

A munkáltatóval kapcsolatos egyéb lényeges információ: A foglalkoztatás jellege igény esetén részmunkaidő is lehet. Az illetmény a feltüntetetteken túl megegyezés szerint módosulhat. 